
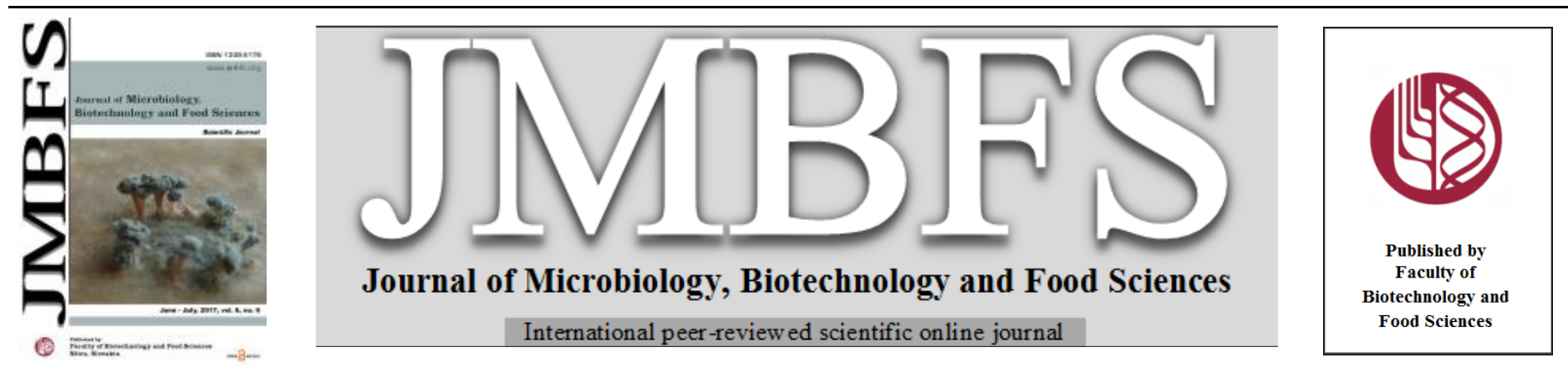

\title{
ISOLATION OF LIPOLYTIC BACTERIA FROM COLOMBIAN ANDEAN SOILS: A TARGET FOR BIOPROSPECTING
}

\author{
Paola Andrea Palacios Jaramillo ${ }^{1,3}$, Daniel Borda-Molina, ${ }^{1,4}$, José Salvador Montaña $*^{1}$ Sandra Baena ${ }^{1,2}$ \\ Address(es): \\ ${ }^{1}$ Department of Microbiology, Pontificia Universidad Javeriana, , Bogotá, Colombia. \\ ${ }^{2}$ Unidad de Saneamiento y Biotecnología Ambiental, Departament of Biology, Pontificia Universidad Javeriana, Bogotá, Colombia. \\ ${ }^{3}$ Department of Biology and Nordic Center for Earth Evolution (NordCEE), University of Southern Denmark, Odense, Denmark. \\ ${ }^{4}$ Institute of Animal Science. Animal Nutrition Group. University of Hohenheim. Stuttgart, Germany.
}

*Corresponding author: jose.montana@javeriana.edu.co

doi: $\underline{10.15414 / j m b f s .2017 .6 .6 .1250-1256}$

\section{ARTICLE INFO}

Received 14.11.2016

Revised 8. 3. 2017

Accepted 10. 4. 2017

Published 1. 6. 2017

Regular article

OPEN $\partial_{\text {ACCESS }}$

\begin{abstract}
Microbial enrichments with a substrate of interest could enhance the possibility of finding certain desired metabolic activities. As lipases are one of the most important enzymes in industrial applications, the Colombian Andean soils were explored as a source of lipolytic microorganisms. Two Andean soils under low temperatures were sampled: paramo and glacier soils from "Los Nevados" National Natural Park. Both soils were enriched through a fed-batch fermentation using olive oil as the inductor substrate. Forty-three lipolytic isolates were obtained and their taxonomic assignments were performed on the basis of $16 \mathrm{~S}$ rDNA gene sequencing. In both cases, the phylum Proteobacteria represented the majority of the isolates. Qualitative assays to measure the lipolytic activity were performed by using tributyrin, triolein or olive oil (1\%). Two isolates identified as Pseudomonas psychrophila and Stenotrophomonas rhizophila produced the largest hydrolysis halos, with an optimal activity at $\mathrm{pH} 8$ and $50^{\circ} \mathrm{C}$. Only the $S$. rhizophila extracellular fraction hydrolyzed short and long chain pNP-esters, including pNP-palmitate. The broader substrate specificity of this isolate is probably due to the simultaneous presence of lipase and esterase activity in the crude extract. This is the first report of lipolytic activity in S. rhizophila, and the first preliminary characterization of the novel lipolytic activity in S. rhizophila and P. psychrophila. Further work is needed to purify and completely characterize the esterases and lipases produced by both species.
\end{abstract}

Keywords: $16 \mathrm{~S}$ rDNA, Fed-batch fermentation, lipase, psychrotrophs

\section{INTRODUCTION}

Lipases are important biocatalysts with innumerable applications in food, dairy, detergent and pharmaceutical industries. The biological function of these enzymes is to catalyze the hydrolysis of triacylglycerols to release free fatty acids, diacylglycerols, mono-acylglycerols and glycerol (Patil et al., 2011). Lipolytic enzymes include esterases commonly defined as carboxyesterases (EC. 3.1.1.1) and lipases, originally called true lipases (Sangeetha et al., 2011). Over the last few decades, lipases have gained special attention for their ability to act in micro-aqueous environments and catalyze esterification, trans-esterification, aminolysis and acidolysis reactions (Joseph et al., 2008).

Bacterial lipases have valuable properties such as a wide variety of substrates, selectivity, stability in organic solvents, and activity in harsh conditions. Other advantages that promote research on these enzymes are their high yield, low production costs and the possibility of genetic manipulation (Glogauer et al., 2011; Meilleur et al., 2009). Most of the lipases in industry are lipoproteins found in genera such as: Achromobacter, Acinetobacter, Bacillus, Burkholderia, Pseudomonas, Staphylococcus, Chromobacterium, among others (Castilla et al., 2017; Soliman et al., 2007). These lipases can be used in different applications including production of fats and oils, detergents, fine chemicals, pharmaceutical drugs, pulp and paper, as well as use in bioremediation, waste treatment, oil biodegradation and medical applications (Stergiou et al., 2013).

The low stability of well-characterized mesophilic enzymes under extreme conditions has prompted the search for new enzymes with better properties (Tirawongsaroj et al., 2008; Jiménez et al., 2012; López et al., 2014). Thus, the isolation of novel microorganisms capable of producing stable lipases for industrial applications is required (Messiasa et al., 2009; Abol et al., 2016). Extreme environments with low temperatures are the most common places to find psychrophilic bacteria with lipolytic activity (De Pascale et al., 2012; De Santi et al., 2016). Cold-adapted microorganisms produce lipases which function effectively at cold temperatures with high rates of catalysis, in comparison to those lipases synthesized by mesophiles or thermophiles that show low, or no activity at low temperatures (Joseph et al., 2008). Some of the adaptations found in enzymes from extreme environments include structural flexibility, higher content of alpha helix compared to beta- sheets and temperature independent reaction rates (Dalmaso et al., 2015).

Previous studies have reported direct functional screening to isolate lipolytic microorganisms through enrichment cultures with lipid substrates including oils (olive oil, palm oil, oil mill), fatty acids and glycerol (Yao et al., 2013; Gombert et al., 1999). Hence the enrichment cultivation in olive oil used in this study, was carried out based on the assumption that microorganisms able to survive on this substrate can synthesize lipases (Gaoa et al., 2000). One of the advantages of this technique is the accumulation of microorganisms with useful enzymes in growthcontrolled conditions (Ekkers et al., 2012).

The major aim of this study was to isolate lipolytic bacteria from low temperature environs found in the paramo and glacier soils from "Los Nevados" National Natural Park. The screening of lipolytic bacteria through the enrichment culture strategy, followed by the bacterial identification by $16 \mathrm{~s}$ rDNA sequencing, and the preliminary enzyme characterization at different conditions (temperatures, $\mathrm{pH}$ and substrates) were the main steps that allowed us to bioprospect for putative novel lipases.

\section{MATERIALS AND METHODS}

\section{Soil samples}

Samples were taken from two cold environments in "Los Nevados" National Natural Park (Manizales - Colombia). The glacier soil sample (44 $47^{\prime} 44.98^{\prime \prime}$ LN $75^{\circ} 21^{\prime} 52.33^{\prime \prime} \mathrm{LW}$ at $5200 \mathrm{MAMSL}$ ) registered $4,1^{\circ} \mathrm{C}$ and $\mathrm{pH} 4,18$. The sample from Paramo, rhizosphere-associated ( $4^{\circ} 51^{\prime} 51.1^{\prime \prime} \mathrm{LN} 75^{\circ} 21^{\prime} 13.7^{\prime \prime} \mathrm{LW}$ at 4322 MAMSL) registered $9^{\circ} \mathrm{C}$ and $\mathrm{pH} 4,88$. Both samples were taken between 10 and 15 centimeters depth. The physico-chemical soil analysis was determined according to Tedesco et al., (1995) including: $\mathrm{pH}$, soil texture, electrical conductivity E.C. (ds/m), cation exchange capacity C.E.C (me/100), organic carbon percentage (\%OC), phosphorus, potassium, sulfur, calcium, iron, and magnesium. All samples were stored at $4^{\circ} \mathrm{C}$ until they were used. 


\section{Enrichment culture}

The inoculum preparation started with the samples being washed in mineral salt medium (MSM), supplemented with tween $20(0.5 \%)$ and olive oil $1 \%$. This procedure was performed with eight grams of soil for each environment, followed by a 24 hours incubation at $140 \mathrm{rpm}$ and at $22^{\circ} \mathrm{C}$ (Wang et al., 2005) After sedimentation, the supernatant was used as inoculum $(10 \%)$ for the enrichment culture. This was performed with the same supplemented medium, in a fermenter batch adjusted to $1 \mathrm{~L}$ bioreactor. The effective volume was $70 \%$, and the cultures conditions were $22^{\circ} \mathrm{C}, 140 \mathrm{rpm}, \mathrm{pH} 6.9$ and $1.6 \mathrm{~L} \mathrm{~min}^{-1}$ of aeration during 3 weeks (Lanser et al., 2002; Henne $\boldsymbol{e t}$ al., 2000). Every 5 days the bioreactor was fed with MSM ensuring the final effective volume. CFU mL ${ }^{-1}$ was estimated in nutrient agar (MoBio), (Köhler, 2007; Wang et al., 2005).

\section{Isolation and morphological description}

Functional screening was carried out at the end of the enrichment in MSM agar supplemented with olive oil or tributyrin at $22^{\circ} \mathrm{C}$ after three days (Bunterngsook et al., 2010; Ertugrul et al., 2007). Colonies with hydrolysis halos were isolated and preserved in $15 \%$ glycerol solution at $-80^{\circ} \mathrm{C}$. The morphological description of colonies was performed and Gram staining was also included to verify cell shape and cell wall properties.

Lipase assay

Lipase production and secretion was evaluated in triplicate by agar diffusion assay. Briefly, MSM agar plates were supplemented with $1 \%$ of tributyrin, olive oil or triolein (Chakravarthy \& Narasu, 2012). As preinoculum, one full loop of the isolated colonies was transferred in $10 \mathrm{ml} \mathrm{LB}$ broth at $20^{\circ} \mathrm{C}$ for 24 hours After incubation, $5 \mu \mathrm{l}$ of the inoculum was then transferred on filter paper disks and incubated on agar plates at $20^{\circ} \mathrm{C}$ for 8 days. The strains were examined daily for their ability to produce clarified zones (Golani et al., 2016).

\section{DNA extraction, amplification and sequencing of 16S rDNA gene}

Total DNA was extracted from the isolates as previously described (Spanevello et al., 2002). Universal primers 27F (5'-AGAGTTTGATCMTGGCTCAG-3') and 1492R (5'-GGTTACCTTGTTACGACTT-3') (Sarkar et al., 2014) were used to obtain a PCR product of $1.5 \mathrm{~Kb}$. A $100 \mu \mathrm{L}$ reaction contained buffer $1 \mathrm{X}$, $\mathrm{MgCl} 1.5 \mathrm{mM}$, dNTPs $0.2 \mathrm{mM}, 0.3 \mu \mathrm{M}$ of each primer, $0.5 \%$ of BSA and Taq Polymerase Promega 1U. PCR was carried out by an initial denaturation at $94^{\circ} \mathrm{C}$ for $5 \mathrm{~min}$; then 30 cycles of denaturation at $94^{\circ} \mathrm{C}$ for $30 \mathrm{sec}$, annealing at $57^{\circ} \mathrm{C}$ for $45 \mathrm{sec}$, extension at $72^{\circ} \mathrm{C}$ for $1 \mathrm{~min}$ y $30 \mathrm{sec}$ and finally an extension cycle at $72^{\circ} \mathrm{C}$ for $7 \mathrm{~min}$. PCR products were analyzed by electrophoresis $1.5 \%$ (wt/vol) agarose gels with SyBR-safe (InvitroGen ${ }^{\mathrm{TM}}$ ). The PCR products were sequenced via the Sanger method by Macrogen Inc. Korea.

\section{Sequence alignments and phylogenetic analysis}

The 16S rDNA sequences were analyzed using BLAST (http://www.ncbi.nlm.nih.gov/BLAST) and the best hit was assigned to the query. Distance trees were constructed using the UPGMA algorithm, (Bisht \& Panda, 2011) with the MEGA $7.0^{\circledR}$ package. The alignments were performed through CLUSTAL omega http://www.ebi.ac.uk/Tools/msa/clustalo0w2/). Bootstrap resampling analysis for 1000 replicates was performed to estimate the confidence of tree topologies (Felsenstein, 1985). The sequences were submitted to the European Molecular Biology Laboratory (EMBL-ENA) Nucleotide Sequence Database (http://www.ebi.ac.uk/embl/Submission/webin.html). The accession numbers of the nucleotide sequence data are listed in Table 1.

\section{Growth curve experiments}

The three strains that produced the largest hydrolysis halos, Stenotrophomonas rhizophila (strain USBA 843E), Pseudomonas psychrophila (strains USBA 844A, USBA 846E) were inoculated in Bioscreen ${ }^{\circledR}$ plates in triplicate with 200 $\mu \mathrm{l}$ as final volume and an $\mathrm{OD}_{540}$ adjusted to 0.02 . Optical density was determined at $20^{\circ} \mathrm{C}$ each $6 \mathrm{~h}$ for 80 hours in order to obtain the their growth curves.

\section{Lipase activity}

USBA 843E, USBA 844A and USBA 846E strains were cultured in LB broth supplemented with olive oil $1 \%$ as inductor substrate at $20^{\circ} \mathrm{C}$ for 72 hours and $140 \mathrm{rpm}$. Then, they were centrifuged at $10.000 \mathrm{rpm}$ for 7 minutes to recover the supernatant. The protein content was determined using the Bradford method (Bradford, 1976) and the enzymatic reaction was measured in triplicate in the Bioscreen ${ }^{\circledR}$. For this reaction, $20 \mu$ of supernatant were added to $180 \mu$ l of buffer Tris- $\mathrm{HCl} 0.1 \mathrm{M}$ and $0.1 \mathrm{mM}$ of lipid substrate emulsified in isopropanol (Rashid et al., 2001). The pNP-esters evaluated were: acetate, butyrate, decanoate and palmytate at $5^{\circ} \mathrm{C}, 10^{\circ} \mathrm{C}, 20^{\circ} \mathrm{C}, 30^{\circ} \mathrm{C}, 40^{\circ} \mathrm{C}, 50^{\circ} \mathrm{C}$ and $60^{\circ} \mathrm{C}$. The optimum $\mathrm{pH}$ of lipolytic activity of the strains was determined between 3 and 9 , using $0.1 \mathrm{M}$
Glycine- $\mathrm{HCl} \mathrm{pH} 3 ; 0.1 \mathrm{M}$ Acetate $\mathrm{pH} 4$ and 5; $0.1 \mathrm{M}$ phosphate $\mathrm{pH}$ 6; $0.1 \mathrm{M}$ Tris$\mathrm{HCl} \mathrm{pH} 7.8$ and 9. This assay was carried out for $1 \mathrm{~h}$ at $30^{\circ} \mathrm{C}$ including biological triplicates. The activity was evaluated measuring the liberated p-nitrophenol at $405 \mathrm{~nm}$. One unit of activity was defined as the amount of enzyme needed to release $1 \mu \mathrm{mol}$ of $\mathrm{p}$-nitrophenol per min.

\section{Statistical analyses}

The results obtained from the lipase activity assay were analyzed through the SPSS software (version 12.0). The analyses were performed using the ShapiroWilk Normality Test, and the pairwise comparison Kruskal-Wallis (Nonparametric) test to establish differences between the three substrates. The homogeneous subgroups test was used to select the strains with the best lipolytic activity.

\section{RESULTS}

\section{Physico-chemical soil properties}

The PNN glacier soil had special physicochemical properties due to its lack of vegetation, low temperature $\left(4.1^{\circ}\right)$, acidity (4.18), loamy texture, low percentage of organic Carbon $(0,23 \%)$, high concentration of iron (385 ppm), phosphorus (94 ppm) and sulfate (88 ppm). Moreover, Paramo soil showed a similar $\mathrm{pH}$ (4.88), but a silt loam texture, with higher concentrations of potassium (85 ppm), calcium (333 ppm) magnesium $(58 \mathrm{ppm})$, and organic carbon $(5,7 \%)$, probably influenced by the presence of vegetation like Espeletia and Calamagrostis.

\section{Enrichment culture and isolation of lipolytic bacteria}

The initial $\mathrm{pH}$ was adjusted to $7 \pm 0.2$, and it decreased around 6.0 after 3 days Regarding cell density, the paramo enrichment culture increased its initial cell

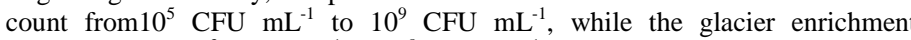
increased from $10^{3} \mathrm{CFU} \mathrm{mL} \mathrm{m}^{-1}$ to $10^{8} \mathrm{CFU} \mathrm{mL}^{-1}$. After the screening a total of 43 colonies were isolated, 30 from the paramo enrichment and 13 from the glacier.

\section{Morphological description}

The most common colony morphologies for the bacterial isolates were: wrinkled, mucoid, viscous, and translucent, with irregular and regular shapes, and with white, pale yellow or yellow tones. Exopolysaccharide production was observed in some isolates. Some colonies could change the morphotype after transferring to a new agar plate. Nevertheless, the microscopic observation showed the same Gram-negative, rod-shaped bacteria.

\section{Lipase assay}

After 8 days of incubation at $20^{\circ} \mathrm{C}$, six of the 43 isolates presented significant hydrolysis halos (statistical analysis). Isolates USBA 851A (Pseudomonas fragi), USBA 852C (Ralstonia pickettii), USBA 843E (Stenotrophomonas rhizophila), and USBA 844A (Pseudomonas psychrophila) produced the major hydrolysis halos in the tributyrin agar plates with diameters between $7 \mathrm{~mm}$ to $11 \mathrm{~mm}$ (Excluding the colony diameter). In triolein, the isolates USBA 844A and USBA 846E (Pseudomonas psychrophila) showed halos between $8 \mathrm{~mm}$ and $10 \mathrm{~mm}$. In olive oil, the isolates USBA 851A (Pseudomonas fragi), USBA 851D (Pseudomonas fragi) and USBA 846E (Pseudomonas psychrophila) produced halos between 5 and $7 \mathrm{~mm}$ of diameter (Fig 1).

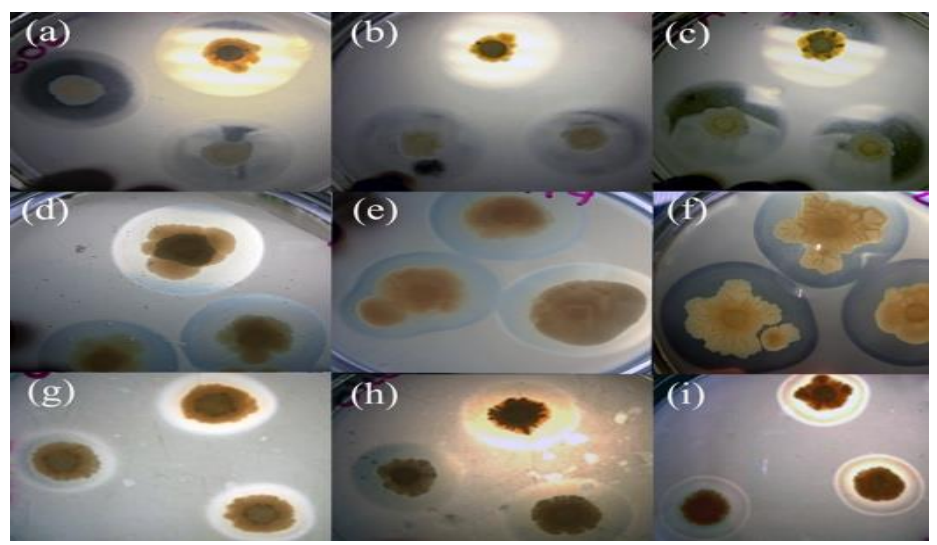

Figure 1 Hydrolysis halos obtained in tributyrin agar plates: a. USBA $851 \mathrm{~A} \mathrm{~b}$ USBA 852C c. USBA 844A. Triolein: d. USBA 851A e. USBA 844A f. USBA 846E. Olive oil: g. USBA $851 \mathrm{~A}$ h. USBA $851 \mathrm{D}$ i. USBA $846 \mathrm{E}$ 
As previously mentioned, Stenotrophomonas rhizophila and Pseudomonas psychrophila, among other isolates, produced the largest hydrolysis halos on the evaluated substrates. We note this fact because the lipolytic activity from Stenotrophomonas rhizophila has not been reported until now. This species of Stenotrophomonas is characterized by the absence of lipase and $\beta$-glucosidase production (Wolf et al., 2002). Additionally, the lipolytic activity of Pseudomonas psychrophila has been reported but it has not been evaluated. This finding led us to choose these isolates (USBA 843E, USBA 844A/USBA 846E) to perform the enzymatic activity assays on, in order to find novel lipases from psychrophilic bacteria.

\section{Sequence alignments and phylogenetic analysis}

The 16S rDNA gene sequences were compared with sequences reported in the GeneBank database using BLAST and the Ribosomal Database Project (RDPII), in order to determine the taxonomic assignment of the 43 isolates. The percent identities obtained were $99 \%$ and $100 \%$, while the e-value was equal to zero (Tab $1)$.

Table 1 Taxonomic assignment of lipolytic bacterial isolates using BLASTN and accession numbers.

\begin{tabular}{|c|c|c|c|}
\hline Code & Nearest BLAST (AC NCBI) & $\%$ Identity & Accession numbers \\
\hline \multicolumn{4}{|l|}{ Glacier } \\
\hline USBA 849A & Pseudomonas mandelii (LT629796.1) & $99 \%$ & LT627086 \\
\hline USBA 843A & Stenotrophomonas rhizophila (KY474340.1) & $99 \%$ & LT627087 \\
\hline USBA $850 \mathrm{~A}$ & Burkholderia fungorum (LN868266.1) & $100 \%$ & LT627088 \\
\hline USBA 852A & Ralstonia pickettii (KT354655.1) & $100 \%$ & LT627089 \\
\hline USBA 843B & Stenotrophomonas rhizophila (KY474340.1) & $99 \%$ & LT627090 \\
\hline USBA 852B & Ralstonia pickettii (KT354650.1) & $100 \%$ & LT627091 \\
\hline USBA 849B & Pseudomonas mandelii (KU921563.1) & $100 \%$ & LT627092 \\
\hline USBA $843 C$ & Stenotrophomonas rhizophila (KR065721.1) & $100 \%$ & LT627093 \\
\hline USBA 851A & Pseudomonas fragi (KX588592.1) & $99 \%$ & LT627094 \\
\hline USBA $852 \mathrm{C}$ & Ralstonia pickettii (KY523570.1) & $100 \%$ & LT627095 \\
\hline USBA 851B & Pseudomonas fragi (KX588591.1) & $100 \%$ & LT627096 \\
\hline USBA $851 \mathrm{C}$ & Pseudomonas fragi (KX068625.1) & $99 \%$ & LT627097 \\
\hline USBA 853A & Dermacoccus nishinomiyaensis (CP008889.1) & $99 \%$ & LT627098 \\
\hline \multicolumn{4}{|l|}{ Paramo } \\
\hline USBA 841A & Aeromonas bivalvium (KY124169.1) & $99 \%$ & LT627099 \\
\hline USBA $842 \mathrm{~A}$ & Aeromonas veronii (KY124169.1) & $99 \%$ & LT627100 \\
\hline USBA 842B & Aeromonas veronii (KY124169.1) & $99 \%$ & LT627101 \\
\hline USBA 843D & Stenotrophomonas rhizophila (KR065721.1) & $99 \%$ & LT627102 \\
\hline USBA $843 \mathrm{E}$ & Stenotrophomonas rhizophila (KM114951.1) & $99 \%$ & LT627103 \\
\hline USBA $843 \mathrm{~F}$ & Stenotrophomonas rhizophila (KM114951.1) & $99 \%$ & LT627104 \\
\hline USBA 844A & Pseudomonas psychrophila (LT629795.1) & $100 \%$ & LT627105 \\
\hline USBA $843 G$ & Stenotrophomonas rhizophila (KR065721.1) & $99 \%$ & LT627106 \\
\hline USBA $843 \mathrm{H}$ & Stenotrophomonas rhizophila (KY474340.1) & $99 \%$ & LT627107 \\
\hline USBA 849C & Pseudomonas mandelii (LT629796.1) & $99 \%$ & LT627108 \\
\hline USBA 843I & Stenotrophomonas rhizophila (KR065721.1) & $99 \%$ & LT627109 \\
\hline USBA 843J & Stenotrophomonas rhizophila (KM114951.1) & $99 \%$ & LT627110 \\
\hline USBA $843 \mathrm{~K}$ & Stenotrophomonas rhizophila (KR065721.1) & $99 \%$ & LT627111 \\
\hline USBA 843L & Stenotrophomonas rhizophila (KR259225.1) & $99 \%$ & LT627112 \\
\hline USBA $843 \mathrm{M}$ & Stenotrophomonas rhizophila (KR259225.1) & $99 \%$ & LT627113 \\
\hline USBA 846A & Pseudomonas psychrophila (KU173827.1) & $99 \%$ & LT627114 \\
\hline USBA $842 C$ & Aeromonas veronii (KY124169.1) & $99 \%$ & LT627115 \\
\hline USBA 846B & Pseudomonas psychrophila (LT629795.1) & $100 \%$ & LT627116 \\
\hline USBA $845 \mathrm{~A}$ & Pseudomonas lini (KM114930.1) & $100 \%$ & LT627117 \\
\hline USBA 846C & Pseudomonas psychrophila (LT629795.1) & $99 \%$ & LT627118 \\
\hline USBA 846D & Pseudomonas psychrophila (LT629795.1) & $99 \%$ & LT627119 \\
\hline USBA 851D & Pseudomonas fragi (KX588592.1) & $100 \%$ & LT627120 \\
\hline USBA $846 \mathrm{E}$ & Pseudomonas psychrophila (LT629795.1) & $100 \%$ & LT627121 \\
\hline USBA 847A & Pseudomonas jessenii (KU725946.1) & $99 \%$ & LT627122 \\
\hline USBA $843 \mathrm{~N}$ & Stenotrophomonas rhizophila (KR065721.1) & $99 \%$ & LT627123 \\
\hline USBA 8430 & Stenotrophomonas rhizophila (KR259225.1) & $99 \%$ & LT627124 \\
\hline USBA $843 \mathrm{P}$ & Stenotrophomonas rhizophila (KR065721.1) & $99 \%$ & LT627125 \\
\hline USBA 848A & Pseudomonas congelans (LN774224.1) & $99 \%$ & LT627126 \\
\hline USBA 843Q & Stenotrophomonas rhizophila (KY474340.1) & $99 \%$ & LT627127 \\
\hline USBA 849D & Pseudomonas mandelii (JX122162.1) & $99 \%$ & LT627128 \\
\hline
\end{tabular}

The distance tree from glacier enrichment culture includes 4 clades from the phylum Proteobacteria, which are associated with the genera Pseudomonas, Stenotrophomonas, Ralstonia and Burkholderia. The fifth clade belongs to the phylum Actinobacteria, represented by the genus Dermacoccus (Fig 2a). The paramo enrichment culture tree showed only 3 clades. The isolates belong to the phylum Proteobacteria represented by the genera Aeromonas, Pseudomonas and Stenotrophomonas (Fig 2b). 
a)

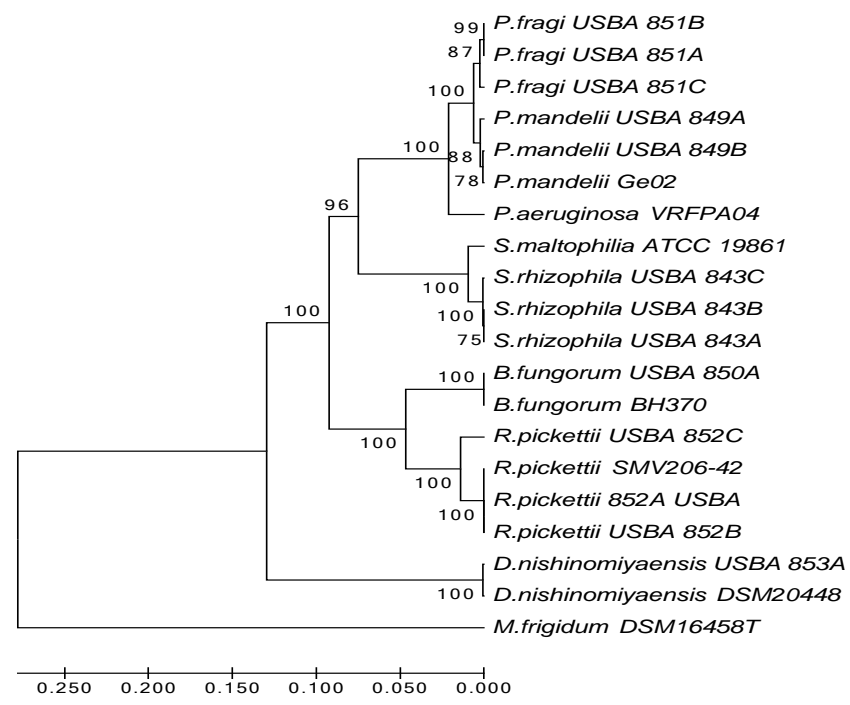

b)

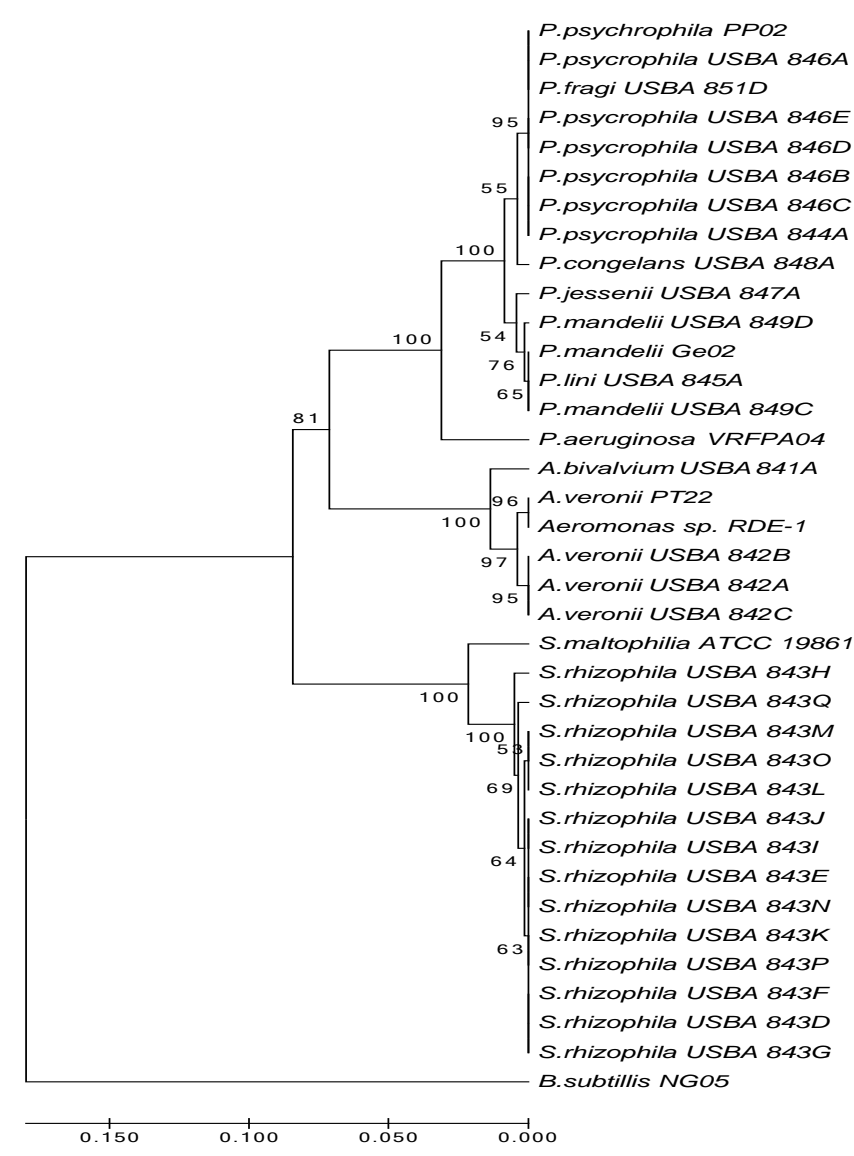

Figure 2 Phylogenetic trees generated with the $16 \mathrm{~S}$ rDNA gene sequence from a) glacier enrichment culture b) paramo enrichment culture, compared with selected reference sequences: P. mandelii Ge02 (KR088369.1), P. aeruginosa VRFPA04 (CP008739.2), S. maltophilia ATCC 19861 (NR 040804.1), B. fungorum BH370 (LN868266.1), $R$. pickettii SMV206-42 (T354655.1), D. nishinomiyaensis DSM20448 (NR 044872.1), $\quad P$. psychrophila PP02 (KU173827.1), A. veronii PT22 (KY124169.1), and Aeromonas sp. RDE-1 (KY365513.1).The trees were generated using the UPGMA method and were rooted with Methanogenium frigidum (NR_104790.1) and Bacillus subtillis (JQ433875.1) as out groups. Scale bar indicates number of substitutions per site and the bootstrap analysis was performed on the basis of 1000 replicates

\section{Growth curve experiments}

The late stationary phase from the isolates USBA 843E (Stenotrophomonas rhizophila), USBA 844A and USBA 846E (Pseudomonas psychrophila) was reached after 72 hours of incubation. In this phase, the extracellular fraction was obtained to perform the p-nitrophenyl ester assays.

\section{Lipase activity}

The protein concentrations obtained from the extracellular fraction were: 0.108 $\mathrm{mg} \mathrm{mL}^{-1}$ for the strain USBA 843E (S. rhizophila), $0.126 \mathrm{mg} \mathrm{mL}^{-1}$ for USBA 844A ( $P$. psychrophila) and $0.092 \mathrm{mg} \mathrm{mL}^{-1}$ for USBA $846 \mathrm{E}(P$. psychrophila) The lipase activity essay was carried out for $1 \mathrm{~h}$ at $30^{\circ} \mathrm{C}$ with four lipid substrates: pNP-acetate, pNP-butyrate, pNP-decanoate and pNP-palmitate. Shortchain pNP-esters ( $\mathrm{C} 2$ and $\mathrm{C} 4)$ were hydrolyzed for the three isolates. Only the USBA 843E (S. rhizophila) showed activity with the four substrates including pNP-palmitate. The broader substrate specificity of this isolate is probably due to the simultaneous presence of lipase and esterase activity in the crude extract (Fig $3)$.

\section{Effect of temperature on enzyme activity}

The USBA 843E (S. rhizophila) enzyme fraction showed maximal activity at $50^{\circ} \mathrm{C}$ in the four lipid substrates. Its highest activity was in short chain $(\mathrm{C} 2$ and C4) fatty acids. The extracellular fraction from USBA 844A (P. psychrophila) had high activity at $50^{\circ} \mathrm{C}$ in pNP-butyrate and at $40^{\circ} \mathrm{C}$ in pNP-acetate. Finally, the USBA $846 \mathrm{E}$ ( $P$. psychrophila) showed its optimum activity at $50^{\circ} \mathrm{C}$ in pNPacetate, pNP-butyrate and pNP-decanoate, and its highest activity was in short chain ( $\mathrm{C} 2$ and $\mathrm{C} 4$ ) fatty acids (Fig 3 ). The $\mathrm{pH}$ used during the temperature assays was 7.

\section{Effect of pH on lipase activity}

The three isolates showed their optimal lipolytic activity at $\mathrm{pH} 8$ in all the lipid substrates except for pNP-butyrate that was highly hydrolyzed at $\mathrm{pH} 9$. For the isolate USBA 843E (S. rhizophila), the hydrolytic activity was observed at $\mathrm{pH} 7$ in $\mathrm{C} 2$ and $\mathrm{C} 4, \mathrm{pH} 8$ in all the lipid substrates, and $\mathrm{pH} 9$ in $\mathrm{C} 4$ and $\mathrm{C} 10$ (Fig 3). The lipase from USBA 844A (P. psychrophila) showed activity at pH 7-8 in C2, and at pH 8-9 in C4 (Fig 3). For the isolate USBA 846E ( $P$. psychrophila), the $\mathrm{C} 2$ hydrolysis was carried out at $\mathrm{pH} 6$ to 9 ; of $\mathrm{C} 4$ at $\mathrm{pH} 8-9$ and $\mathrm{C} 10$ at $\mathrm{pH} 8$ (Fig 3). The temperature used during the $\mathrm{pH}$ assays was $20^{\circ} \mathrm{C}$. 

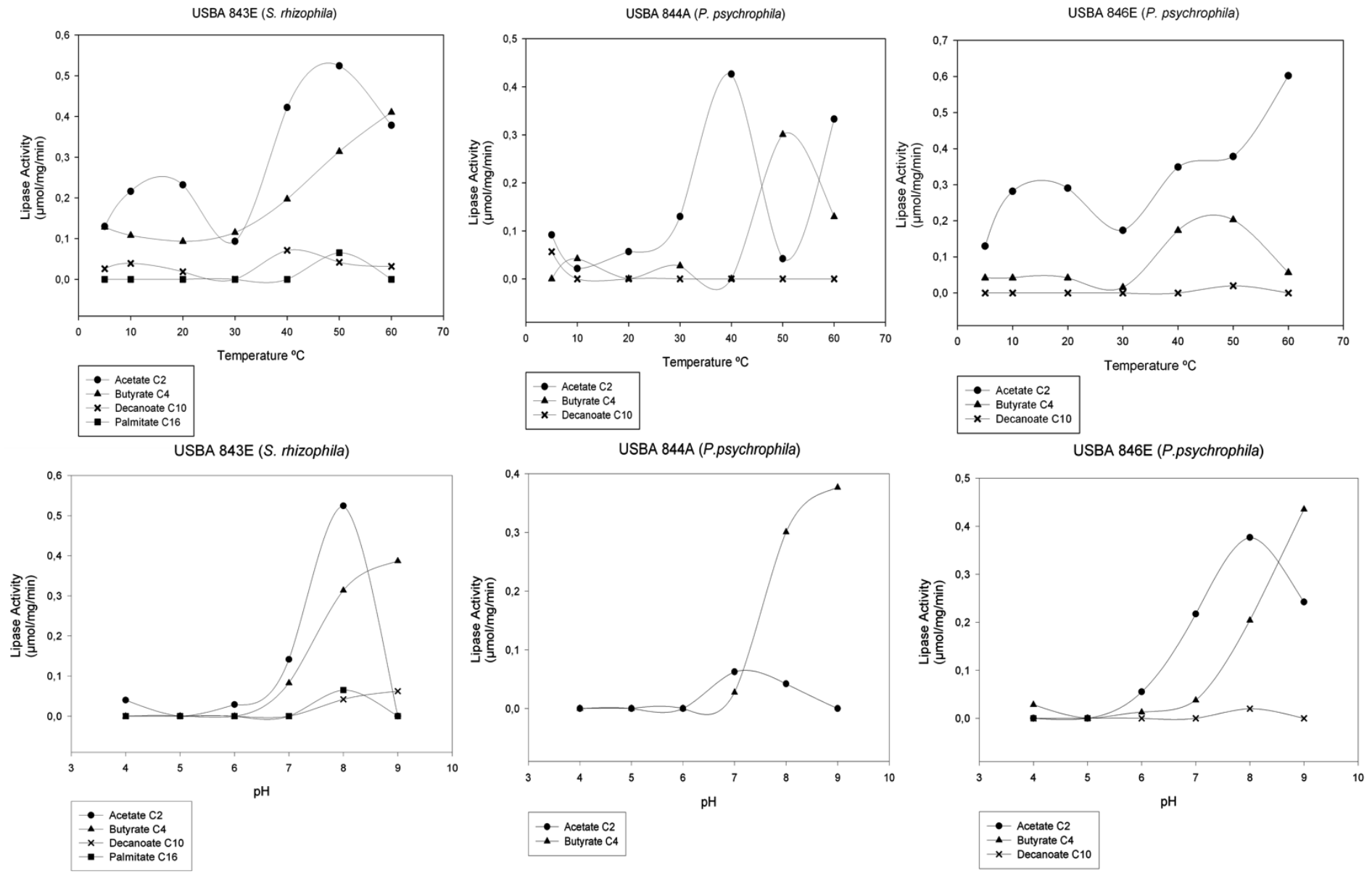

Figure 3 Lipolytic activities from the isolates USBA 843E, USBA 844A and USBA 846E at different temperatures and pH.

\section{DISCUSSION}

Enrichment of environmental samples with a substrate of interest aimed to expose microorganisms under a selection pressure. Here the "survival of the fittest" takes place under different physical, chemical and nutritional conditions (Li et al., 2009). The adaptation of natural and complex microbial communities to specific conditions (e.g. degradation of olive oil) can increase the prevalence of microbes carrying special metabolic capacities such as lipolytic activity (DeAngelis et al., 2010).

Pseudomonas and Stenotrophomonas were the most abundant genera recovered from the enrichments, and they also exhibited the largest hydrolysis halos. This shows how their ability to metabolize the given substrate allowed them to increase their population compared to other lipolytic bacteria. Bardgett et al. (2005) reported that the diversity tends to fall when the better-adapted microorganism dominates the community. In our case, the better-adapted microorganisms with the ability and required enzymes to degrade the nonconventional substrate, dominated the enrichment culture communities.

Furthermore, when we compared the lipolytic isolates from both soils, we found greater species diversity in the glacier enrichment culture than the one obtained from paramo. This is counter intuitive to expectation if we consider that the optimal environmental conditions, in terms of temperature, humidity and nutrient availability were present in the paramo soil (Buytaert et al., 2006). In this case it is necessary to take into account that the enrichment method involved changes in the dynamics of the community. This could be caused predominantly by the microbial interactions within the bioreactor and the selection pressure in olive oil (Bardgett et al., 2005).

The phyla Proteobacteria and Actinobacteria (with Dermacoccus nishinomiyaensis as the only isolate) identified in the glacier enrichment cultures have been reported from other cold environments (Cheng \& Foght, 2007; Steven et al., 2007; Neufeld et al., 2004; Shivaji et al., 2006). However, some studies also indicate the presence of different taxa such as Bacteroidetes and Firmicutes. They also report the presence of psychrophilic and lipolytic bacteria including Pseudomonas, Aeromonas, Burkholderia and Ralstonia, (Yuan et al., 2010; Joseph et al., 2008; Hemachander \& Puvanakrishnan, 2000) which were also found in our enrichment cultures.

One particular finding in our study was the isolation of bacteria with different colony morphotypes. This polymorphism complicated the macroscopic description of some of the isolates, but after finishing the bacterial identification, this change was observed only for the Pseudomonas isolates. Workentine $\boldsymbol{e t}$ al. (2010) described that Pseudomonas can change its colony morphotype depending on the culture conditions.

In terms of lipolytic activity, this potential for Pseudomonas fragi and Ralstonia picketti was confirmed by the large hydrolysis halos produced in the fatty substrates (Fig 1 and 3). These species have been previously reported for their lipolytic activity and stability at low temperatures (Joseph et al., 2008; Hemachander \& Puvanakrishnan, 2000). The other two isolates with interesting activity were Pseudomonas psychrophila and Stenotrophomonas rhizophila. They were chosen to perform enzymatic activity assays, not only for the production of hydrolysis halos, but also for their "novelty" value. Bai \& Rai Vittal. (2014) studied the relationship between protease and lipase production with quorum sensing molecules in P. psychrophila PSPF19. Their objective was to inhibit the exoenzyme production. Therefore, they never characterized the lipases or proteases produced by the strain PSPF19. The closest report of the lipolytic activity in $P$. psychrophila, was performed by Yumoto et al. (2001) with Pseudomonas fragi lipase, which has a close phylogenetic association with $P$. psychrophila. In conclusion, our study is the first to date to perform the preliminary characterization of its lipolytic activity.

In 2002 Wolf et al. did the whole characterization of Stenotrophomonas rhizophila, a novel plant-associated bacterium. In their study they reported that the three strains evaluated showed a high antifungal activity and no lipase or $\beta$ glucosidase production, which differs from the characteristics observed from the 13 strains of $S$. maltophila. In addition, the growth rate of $S$. rhizophila at $4^{\circ} \mathrm{C}$ was 6.25 times higher than the observed with $S$. maltophila, which lead us to predict an even higher potential for the purified enzyme of $S$. rhizophila at low temperatures. After this publication, Hasan-Beikdashti et al. (2008) optimized the culture conditions to produce the $S$. maltophila lipase to hydrolyze capsaicin and produce vanillylamine, which has antibacterial and anti-inflammatory properties. Li et al. in 2013 and 2016 cloned and characterized the lipases: CGMCC 4254 (novel cold-active and organic solvent-tolerant lipase), and the GS11 (cold-active, solvent-tolerant and alkaline) also from $S$. maltophila Nevertheless, this is the first study that reports the lipolytic activity in $S$. rhizophila.

The optimal conditions for the three evaluated strains were $50^{\circ} \mathrm{C}$ and $\mathrm{pH} 8$ (Fig 8). Those temperatures and $\mathrm{pH}$ conditions have been already evaluated in Pseudomonas aeruginosa (Dharmsthiti et al., 1998), Pseudomonas fluorescens (Kulkarni et al., 2002), Pseudomonas sp. INK1 isolated in the Antarctic (Park et al., 2012). Our possible "novel" alkaline enzymes should be purified and tested 
for a complete characterization in order to explore all the potential in terms of stability, substrate specificity and possible applications.

\section{CONCLUSION}

Exposing microorganisms to specific conditions in order to screen for capabilities that are not usually explored in non-conventional environments is a useful tool to discover biotechnological applications. Our study reports the first preliminary characterization of the lipolytic activity of Stenotrophomonas rhizophila and Pseudomonas psychrophila. Further studies to purify and completely characterize their lipolytic enzymes, will help us to understand all the potential offered by these "novel" lipases/esterases, that could be used for future applications. Our results demonstrate the vast opportunities offered by extreme environments for exploration and bioprospecting of different metabolic activities of interest.

Acknowledgments: We would like to thank to Fabio Roldan and Ziv Arbeli from the Unidad de Saneamiento y Biotecnología Ambiental (USBA) for providing us access to the Bioscreen. Also to Oona Snoeyenbos-West and Carolin Löscher from the Nordic Center for Earth Evolution (NordCEE) for comments that greatly improved the manuscript. This work was financially supported by the Colombian Center for Genomics and Bioinformatics of Extreme Environments GeBiX and Colciencias - SENA (6570-392-19990) and was done under MAVDT contract No. 15, 2008 and UAESPNN Research Permit No. DTNO-N-20/ 2007.

\section{REFERENCES}

Abol, D.M., Bayoumi, R.A., Hassan, M.A. (2016). Production of Thermoalkaliphilic Lipase from Geobacillus thermoleovorans DA2 and Application in Leather Industry. Enzyme Research, 2016. http://dx.doi.org/10.1155/2016/9034364

Bai, J., Rai Vittal, R. (2014). Quorum Sensing Regulation and Inhibition of Exoenzyme Production and Biofilm Formation in the Food Spoilage Bacteria Pseudomonas psychrophila PSPF19. Food Biotechnology, 28(4), 293-308. http://dx.doi.org/10.1080/08905436.2014.963601

Bardgett, R., Usher, M., Hopkins, D. (2005). Biological Diversity and Function in Soils. New York: Cambridge University Press.

Bisht, S.S., Panda, A.K. (2011). Biochemical Characterization and 16S rRNA Sequencing of Few Lipase-Producing Thermophilic Bacteria from Taptapani Hot Water Spring, Orissa, India. Biotechnol Res Int., 2011(452710). http://dx.doi.org/10.4061/2011/452710

Bradford, M. (1976). A rapid and sensitive method for the quantitation of microgram quantities of protein utilizing the principle of protein-dye binding Analytical biochemistry, 72(1-2), 248-254. http://dx.doi.org/10.1016/00032697(76)90527-3

Bunterngsook, B., Kanokratana, P., Thongaram, T., Tanapongpipat, S., Uengwetwanit, T., Rachdawong, S., Vichitsoonthonkul, T., Eurwilaichitr, L. (2010). Identification and characterization of lipolytic enzymes from a peatswamp forest soil metagenome. Biosci Biotechnol Biochem, 74(9), 1848-1854 http://dx.doi.org/10.1271/bbb.100249

Buytaert, W., Deckers, J., Wyseure, G. (2006). Description and classification of non allophanic Andosols in south Ecuadorian alpine grasslands (páramo). Geomorphology, 73(3-4),

http://dx.doi.org/10.1016/j.geomorph.2005.06.012

Castillaa, A., Panizzaa, P., Rodrígueza, D., Boninoa, L., Díaz, P., Irazoquia, G., Rodríguez, S. (2017). A novel thermophilic and halophilic esterase from Janibacter sp. R02,the first member of a new lipase family (Family XVII) Enzyme and Microbial Technology, 98, 86-95. http://dx.doi.org/10.1016/j.enzmictec.2016.12.010

Chakravarthy, K., Narasu, L. (2012). Production and Optimization of Lipase from Bacillus tequilensis NRRL B-41771. International Journal of Biotechnology Applications, 4(1), 134 - 136

Cheng, S.M., Foght, J.M. (2007). Cultivation independent and dependent characterization of Bacteria resident beneath John Evans Glacier. FEMS Microbiol Ecol, 59(2), 318-330. http://dx.doi.org/10.1111/j.1574 6941.2006.00267.x

Dalmaso, G.Z.L., Ferreira, D., Vermelho, A.B. (2015). Marine Extremophiles: A Source of Hydrolases for Biotechnological Applications. Marine Drugs, 13(4), 1925-1965. http://doi.org/10.3390/md13041925

De Angelis, K., Gladden, J., Allgaier, M., D’haeseleer, P., Fortney, J., Reddy, A., Hugenholtz, P., Singer, S., Vander, J.S., Silver, W., Simmons, B., Hazen, T. (2010). Strategies for Enhancing the Effectiveness of Metagenomic-based Enzyme Discovery in Lignocellulolytic Microbial Communities. Bioenerg Res, 3(2), 146 - 158. http://dx.doi.org/10.1007/s12155-010-9089-z

De Pascale, D., De Santi, C., Fu, J., Landfald, B. (2012). The microbial diversity of Polar environments is a fertile ground for bioprospecting. Mar Genomics, 8 15-22. http://dx.doi.org/10.1016/j.margen.2012.04.004

De Santi, C., Altermark, B., Pierechod, M.M., Ambrosino, L., de Pascale, D., Willassen, N.P. (2016). Characterization of a cold-active and salt tolerant esterase identified by functional screening of Arctic metagenomic libraries. $B M C$ Biochem, 17(1). http://dx.doi.org/10.1186/s12858-016-0057-x

Dharmsthiti, S., Pratuangdejkul, J., Theeragool, GT., Luchai, S. (1998). Lipase activity and gene cloning of Acinetobacter calcoaceticus LP009. J Gen Appl Microbiol, 44(2), 139-145.

Ekkers, D.M., Cretoiu, M.S., Kielak, A.M., Elsas, J.D. (2012). The great screen anomaly -- a new frontier in product discovery through functional metagenomics. Appl Microbiol Biotechnol, 93(3), 1005-1020. http://dx.doi.org/10.1007/s00253011-3804-3

Ertugrul, S., Donmez, G., Takac, S. (2007). Isolation of lipase producing Bacillus $s p$. from olive mill wastewater and improving its enzyme activity. Journal of Hazardous Materials, 149(3),

$720-724$

http://dx.doi.org/10.1016/j.jhazmat.2007.04.034

Felsenstein, J. (1985). Phylogenies and the Comparative Method. The American Journalist, 125, 1 - 15

Gaoa, X., Cao, S., Zhang, K. (2000). Production, properties and application to nonaqueous enzymatic catalysis of lipase from a newly isolated Pseudomonas strain. Enzyme Microb Technol, 27(1-2), 74-82. http://dx.doi.org/10.1016/S0141 $\underline{0229(00) 00191-5}$

Glogauer, A., Martini, V. P., Faoro, H., Couto, G. H., Müller-Santos, M., Monteiro, R. A., et al. (2011). Identification and characterization of a new true lipase isolated through metagenomic approach. Microb Cell Fact, 10, 54 http://dx.doi.org/10.1186/1475-2859-10-54

Golani, M., Hajela, K., Pandey, G.P. (2016). Screening, Identification, Characterization and Production of Bacterial Lipase from Oil Spilled Soil Int.J.Curr.Microbiol.App.Sci, http://dx.doi.org/10.20546/ijcmas.2016.503.087

Gombert, A., Pinto, A., Castilho, L., Freire, D. (1999). Lipase production by Penicillium restrictum in solid-state fermentation using babassu oil cake as substrate. Process Biochemistry, 35(1-2), 85-90. http://dx.doi.org/10.1016/S0032-9592(99)00036-9

Hemachander, C., Puvanakrishnan, R. (2000). Lipase from Ralstonia pickettii as an additive in laundry detergent formulations. Process biochemistry, 35(8), 809814. http://dx.doi.org/10.1016/S0032-9592(99)00140-5

Henne, A., Schmitz, R.A., Bömeke, M., Gottschalk, G., Daniel, R. (2000). Screening of environmental DNA libraries for the presence of genes conferring lipolytic activity on Escherichia coli. Appl Environ Microbiol, 66(7), 3113-3116 Jiménez, D.J., Montaña, J.S., Alvarez, D., Baena, S. (2012). A novel cold active esterase derived from Colombian high Andean forest soil metagenome. World $J$ Microbiol Biotechnol, 28(1), 361-70. http://dx.doi.org/doi:10.1007/s11274-0110828-x

Joseph, B., Ramteke, PW., Thomas, G. (2008). Cold active microbial lipases: Some hot issues and recent developments. Biotechnology Advances, 26(5), $457-$ 470. http://dx.doi.org/10.1016/j.biotechadv.2008.05.003

Kulkarni, N., Gadre, R.V. (2002). Production and properties of an alkaline, thermophilic lipase from Pseudomonas fluorescens NS2W. J Ind Microbiol Biotechnol, 28(6), 344-348. http://dx.doi.org/10.1038/sj/jim/7000254

Köhler, U. (2007). Lipolytic enzymes from termophilic enrichment cultures and metagenomes. Dissertation, University of Hamburg

Lanser, A.C., Manthey, L.K., Hou, C.T. (2002). Regioselectivity of new bacteria lipases determined by hydrolysis of triolein. Curr Microbiol, 44(5), 336-340 http://dx.doi.org/10.1007/s00284-001-0019-3

Li, L.L., McCorkle, S.R., Monchy, S., Taghavi, S., van der Lelie, D. (2009) Bioprospecting metagenomes: glycosyl hydrolases for converting biomass Biotechnol Biofuels, 2, 10. http://dx.doi.org/10.1186/1754-6834-2-10

Li, M., Yang, L., Xu, G., Wu, J. (2016). Cloning and characterization of a novel lipase from Stenotrophomonas maltophilia GS11: The first member of a new bacterial lipase family XVI. Journal of Biotechnology, 228(20), 30-36 http://dx.doi.org/10.1016/j.jbiotec.2016.04.034

López, G., Chow, J., Bongen, P., Lauinger, B., Pietruszka, J., Streit, W.R., Baena, S. (2014). A novel thermoalkalostable esterase from Acidicaldus sp. strain USBA-GBX-499 with enantioselectivity isolated from an acidic hot springs of Colombian Andes. Appl Microbiol Biotechnol, 98(20), 8603-16. http://dx.doi.org/10.1007/s00253-014-5775-7

Meilleur, C., Hupé, J. F., Juteau, P., \& Shareck, F. (2009). Isolation and characterization of a new alkali-thermostable lipase cloned from a metagenomic library. $J$ Ind Microbiol Biotechnol, 36(6), 853-861. http://dx.doi.org/10.1007/s10295-009-0562-7

Messiasa, J., Costaa, B., Limab, V., Dekkerc, R., Rezendea, M., Kriegerd, N., Barbosa, A. (2009). Screening Botryosphaeria species for lipases: Production of lipase by Botryosphaeriaribis EC-01 grown on soybean oil and other carbon sources. Enzyme and Microbial Technology, 45(6-7), 426 - 431 http://dx.doi.org/10.1016/j.enzmictec.2009.08.013

Neufeld, J.D., Yu, Z., Lam, W., Mohn, W.W. (2004). Serial analysis of ribosomal sequence tags (SARST): a high-throughput method for profiling complex microbial communities. Environ Microbiol, 6(2), 131-144.

Park, I., Cho, J. (2012). Extracellular lipase of the antarctic bacterial isolate, Pseudomonas $s p$. INK1 as a potential tool for improving the flavor quality of dairy products. African Journal of Agricultural Research, 7(16), $2502-2508$ http://dx.doi.org/10.5897/AJAR11.2127 
Patil, K., Chopda, M., Mohajan, R. (2011). Lipase Biodiversity. Indian Journal of Science and Technology, 4(8), 971-982. http://dx.doi.org/10.17485/ijst/2011/v4i8/30913

Rashid, N., Shimada, Y., Ezaki, S., Atomi, H., Imanaka, T. (2001). Lowtemperature lipase from psychrotrophic Pseudomonas sp. strain KB700A. Appl Environ Microbiol, 67(9), 4064-4069.

Sangeetha, R., Arulpandi I., Geetha, A. (2011). Bacterial Lipases as Potential Industrial Biocatalysts: An Overview. Research Journal of Microbiology, 6, 124. http://dx.doi.org/10.3923/jm.2011.1.24

Sarkar, A., Kazy, S.K., Sar, P. (2014). Studies on arsenic transforming groundwater bacteria and their role in arsenic release from subsurface sediment. Environmental Science and Pollution Research, 21(14), 8645-8662. http://dx.doi.org/10.1007/s11356-014-2759-1

Shivaji, S., Chaturvedi, P., Suresh, K., Reddy, G.S., Dutt, C.B., Wainwright, M., Narlikar, J.V., Bhargava, P.M. (2006). Bacillus aerius sp. nov., Bacillus aerophilus sp. nov., Bacillus stratosphericus $\mathrm{sp}$. nov. and Bacillus altitudinis sp. nov., isolated from cryogenic tubes used for collecting air samples from high altitudes. Int $J$ Syst Evol Microbiol, 56(7), 1465-1473. http://dx.doi.org/10.1099/ijs.0.64029-0 Spanevello, M., Yamamoto, H., Patel, K. (2002). Thermaerobacter subterraneus sp. nov., a novel aerobic bacterium from the Great Artesian Basin of Australia, and emendation of the genus Thermaerobacter. International Journal of Systematic and Evolutionary Microbiology, 52(3), 795-800. http://dx.doi.org/10.1099/00207713-52-3-795

Stergiou, P.Y., Foukis, A., Filippou, M., Koukouritaki, M., Parapouli, M., Theodorou, L.G., Hatziloukas, E., Afendra, A., Pandey, A., Papamichael, E.M (2013). Advances in lipase-catalyzed esterification reactions. Biotechnol Adv, 31(8), 1846-1859. http://dx.doi.org/10.1016/j.biotechadv.2013.08.006

Soliman, N. A., Knoll, M., Abdel-Fattah, Y. R., Schmid, R. D., \& Lange, S. (2007). Molecular cloning and characterization of thermostable esterase and lipase from Geobacillus thermoleovorans $\mathrm{YN}$ isolated from desert soil in Egypt. $\begin{array}{lll}\text { Process } \quad \text { Biochemistry, } & \text { 42(7), }\end{array}$ http://dx.doi.org/10.1016/j.procbio.2007.05.005

Steven, B., Briggs, G., McKay, C.P., Pollard, W.H., Greer, C.W., Whyte, L.G. (2007). Characterization of the microbial diversity in a permafrost sample from the Canadian high Arctic using culture-dependent and culture-independent methods. FEMS Microbiol Ecol, 59( 2), 513-523. http://dx.doi.org/10.1111/j.1574-6941.2006.00247.x

Tedesco, M., Gianello, C., Bissani, C., Volkweiss, S. (1995). Analisé de solo plantas e outros materiais. Porto Alegre: UFRGS.

Tirawongsaroj, P., Sriprang, R., Harnpicharnchai, P., Thongaram, T., Champreda, V., Tanapongpipat, S., Pootanakit, K., Eurwilaichitr, L. (2008). Novel thermophilic and thermostable lipolytic enzymes from a Thailand hot spring metagenomic library. $J$ Biotechnol, 133(1), 42-49. http://dx.doi.org/10.1016/j.jbiotec.2007.08.046

Wang, X., Wang, H., Tan, C. (2005). Degradation and metabolism of hexazinone by two isolated bacterial strains from soil. Chemosphere, 61(10) 1468-1474. http://dx.doi.org/10.1016/j.chemosphere.2005.04.116

Wolf, A., Fritze, A., Hagemann, M., Berg, G. (2002). Stenotrophomonas rhizophila sp. nov., a novel plant-associated bacterium with antifungal properties. Int J Syst Evol Microbiol, 52(6),1937-44. http://dx.doi.org/10.1099/00207713-526-1937

Workentine, M.L., Harrison, J.J., Weljie, A.M., Tran, V.A., Stenroos, P.U., Tremaroli, V., Vogel, H.J., Ceri, H., Turner, R.J. (2010). Phenotypic and metabolic profiling of colony morphology variants evolved from Pseudomonas fluorescens biofilms. Environ Microbiol, 12(6), 1565-1577. http://dx.doi.org/10.1111/j.1462-2920.2010.02185.x

Yao, C., Cao, Y., Wu, S., Li, S., He, B. (2013). An organic solvent and thermally stable lipase from Burkholderia ambifaria YCJ01: Purification, characteristics and application for chiral resolution of mandelic acid. Journal of Molecular $\begin{array}{llll}\text { Catalysis } & B: & \text { Enzymatic, 85, } & 105-\end{array}$ http://dx.doi.org/10.1016/j.molcatb.2012.08.016

Yuan, B., Cai, Y., Liao, X., Yun, L., Zhang, F., Zhang, D. (2010). Isolation and identification of a cold-adapted lipase producing strain from decayed seeds of Ginkgo biloba L. and characterization of the lipase. African Journal of Biotechnology, 9(18), 2661-2667. http://dx.doi.org/10.5897/AJB2010.000-3085

Yumoto, I., Kusano, T., Shingyo, T., Nodasaka, Y., Matsuyama, H., Okuyama, H. (2001). Assignment of Pseudomonas sp. strain E-3 to Pseudomonas psychrophila sp. nov., a new facultatively psychrophilic bacterium. Extremophiles, 5(5), 343-349. 